\title{
TOXICODYNAMICS OF CHLORPYRIFOS AND «IVIN» COMBINED ACTION UNDER PROLONGED ADMISSION
}

\author{
O. Vasetska \\ L.I. Medved's Research Center of Preventive Toxicology, Food and Chemical Safety, \\ Ministry of Health, Ukraine (State Enterprise), Kyiv, Ukraine
}

\begin{abstract}
The combined action of pesticides is one of the problems of toxicology, because in comparison to individual active substances, their mixtures can increase toxicity and delayed action effects, which is a risk to human health. It is known that plant growth regulators $(P G R)$ when applied together with pesticides help to reduce the quantitative rates of pesticides applied, the accumulation of pesticides and heavy metals in plants, reduce the acute toxicity of xenobiotics. The combined effect of the prolonged admission of PGRs and pesticides is an unexplored area, and it is an important issue in preventive toxicology.
\end{abstract}

The Aim of the Research. Determination of the nature of toxic effects of Chlorpyrifos and "Ivin" combined action at subchronic oral admission.

Materials and Methods. Chlorpyrifos and PGR "Ivin" (2.6-dimethyl-N-pyridine oxide) combined action was studied on male Wistar Han rats. Substances were administered orally, via a feeding tube for 13 weeks; Chlorpyrifos was administered in the form of an aqueous emulsion with an auxiliary material OP-10 at a dose of $5 \mathrm{mg} / \mathrm{kg}\left(1 / 15 L D_{50}\right)$, "Ivin" - in the form of an aqueous solution at a dose of $13 \mathrm{mg} / \mathrm{kg}$ and $0.013 \mathrm{mg} / \mathrm{kg}\left(1 / 100\right.$ and $1 / 100000 \mathrm{LD}_{50}$ respectively), the control group of rats was given water with an auxiliary material OP-10. Signs of intoxication were recorded, body weight was measured in 4, 9 and 13 weeks, biochemical indicators of blood serum were determined (the activity of ALT and AST enzymes and alkaline phosphatase; the content of crude protein, urea, cholesterol, triglycerides and glucose were determined using kits of reagents by BioSystems (Spain); cholinesterase (ChE) activity in serum, red blood cells and brain tissue was determined with the use of methodology by Hesrtin S. using a kit of reagents produced by LLC NPP Filisit-Diagnostics (Ukraine).

Results. No clinical signs of intoxication were detected in the experimental groups of rats. Under the isolated use of Chlorpyrifos a significant decrease in body weight, ChE inhibition activity in all bio substrates, with the greatest effect in the brain (by 48.8\%); increase (after 9 and 13 weeks) in the activity of ALT and AST by 26.7-32.6\%, 12.5-12.0\%; a slight but a significant increase in the level of urea and glucose in blood serum to $17.3 \%$ and $17.6 \%$, respectively was detected. Under the combined action of Chlorpyrifos and "Ivin" in specified doses the body weight of rats was at control level, decrease of ChE activity was observed in all biological substrates and was at nearly the same level with the isolated use of Chlorpyrifos. There was a tendency towards the decline in ChE inhibition activity in brain tissue, and under the combined action of Chlorpyrifos with "Ivin" at higher doses after 4 weeks this effect was a significant $(22.15 \%, p<0.05)$.

Conclusions. Chlorpyrifos under the isolated oral admission for 13 weeks has a weak hepatotoxic effect, as evidenced by the increase in cytolysis enzymes and urea levels in serum and causes a moderate anticholinesterase effect. "Ivin" under combined with Chlorpyrifos admission to the organism eliminates the hepatotoxic effects of Chlorpyrifos and reduces its anticholinergic effects in brain, which contributes to a less severe intoxication.

Key Words: Chlorpyrifos, Ivin, hepatotoxic effect, anticholinesterase effect.

Introduction. A special group of chemicals pesticides - are one of the factors of influence on the human body. They are used for different purposes and under certain conditions may increase the risk of negative changes in the environment and human health. Therefore the prevention of risk of such influence of pesticides on the environment and human health is one of the important issues in modern preventive toxicology.

Among the steps to be taken to prevent adverse effects on humans and the environment are the identification of harmful effects of pesticides on the body, determination of risk levels and sound scientific basis for the allowable daily dose (ADD) of pesticides for humans, toxicological and hygienic regulations for pesticides in food, water, air, soil. However, you cannot always predict all the characteristics of the biological effect of pesticides on the body, of their biotransformation and impact on the environment, which can cause the contamination of water, soil, air and inflict harm for human health.

Certain measures may reduce the pressure of pesticides on the environment and human. New chemical plant protection products, which are less toxic and have lower persistence rates in the environment, or selective pesticides with more prolonged protective action and lower rate of consumption, should be developed. Combined application of plant protection products and tank mixtures allows not only to reduce the consumption rate of a single pesticide, but also due to greater range and duration of protective action of drugs, allows to reduce the number of treatments, which looks also promising in the regard of pesticides pres- 
sure reduction. However, among negative consequences of their use, in comparison to the use of individual active substances, there may be an increase in acute and chronic toxicity, mutagenic activity and embryo toxicity of combined drugs for animals, humans [1-12] and non-target environmental objects [13-15], thus more rigorous toxicological and sanitary research and adequate assessment of their harmful effects on the organism is required.

Promising in this area of research is the study of the nature and mechanisms of the combined action of pesticides and plant growth regulators (PGR), which are applied in agricultural practice. A number of scientific papers [16-19] showed that the use of pesticides alongside with PGRs based on methyl derivatives of $\mathrm{N}$-oxide pyridine makes it possible to significantly reduce the consumption of pesticides (up to 50\%) without reducing the protective effect, reduce the accumulation of pesticides and heavy metals in plant products and get cleaner agricultural products.

We proved [20,21] that the combined single exposure to some active substances of pesticides and PGRs based on methyl derivatives of pyridine $\mathrm{N}$-oxide significantly reduces the acute toxicity of pesticides of different chemical groups, as well as the anticholinesterase effect of organophosphorus substances. It is believed that these effects may be associated with antioxidant and membrane-stabilizing action of PGRs.

Combined action of PGRs and pesticides at prolonged admission to the organism has not been studied yet. Therefore it is an important issue for preventive toxicology to study the effect of pesticides and PGRs under combined prolonged admission to the organism, to determine the nature of the combined action and, if necessary, to develop preventive measures to minimize their harmful effects on humans.

The Aim of the Research. Determination of the nature of toxic effects of Chlorpyrifos and "Ivin" combined action at subchronic oral admission.

Materials and Methods. Technical insecticide Chlorpyrifos (97.0\% purity) and growth regulator "Ivin" technical (99.5\% purity) were used in the studies. Chlorpyrifos by its chemical structure is referred to organophosphorus compounds (0.0-Diethyl-O- (3,5,6-trichloro2-pyridinyl) phosphothioate); "Ivin" - to methyl derivatives of $\mathrm{N}$-oxide pyridine (2.6dimethyl-N-oxide pyridine). Both substances are widely used in the agricultural practices in Ukraine [22].

The toxicodynamics of the combined action of Chlorpyrifos and "Ivin" was studied under the conditions of oral administration to Wistar Han rats for 13 weeks, in accordance with OECD 408 (OECD Guideline for the Testing of Chemicals: \#408 "Repeated Dose 90-day Oral Toxicity Study in Rodents", 1998). The research was conducted in accordance with the principles of bioethics and the requirements on humane treatment of animals (European Convention for the Protection of Vertebrate Animals Used for Research and Other Scientific Purposes, 1986).

Since sex-related sensitivity to the test substances is not observed, following the principles of bioethics, studies were performed on male rats. The experiment involved 60 male Wistar Han adult rats with SPF status (specific pathogen free). The animals were obtained from the nursery of "L.I. Medved Research Centre of Preventive Toxicology, Food and Chemical Safety, MH Ukraine" and after five days of acclimatization were divided into 4 groups. Control group (1) and experimental groups $(2,3,4)$ consisted of 15 animals each. Within the period of 13 weeks ( 5 days a week) the rats were fed on an empty stomach via a feeding tube with Chlorpyrifos in the form of an aqueous emulsion with an auxiliary material OP-10 at a dose of $5 \mathrm{mg} / \mathrm{kg}\left(1 / 15 \mathrm{LD}_{50}\right)$ (group 2), control group animals were given distilled water with OP-10 in the same volume. Animals from groups 3 and 4 were given Chlorpyrifos at a dose of $5 \mathrm{mg} / \mathrm{kg}$ and "Ivin" at doses of $13 \mathrm{mg} / \mathrm{kg}$ or $0.013 \mathrm{mg} / \mathrm{kg}(1 / 100$ and $1 / 100000 \mathrm{LD}_{50}$ respectively). The choice of the dose of Chlorpyrifos $(5 \mathrm{mg} / \mathrm{kg}$ ) was based on its specific anticholinergic action, the influence of which at subchronic oral admission by male rats showed the inhibition of the activity of cholinesterase (ChE) in the blood at $42 \%$, and under the conditions of chronic exposure the inhibition of ChE activity in blood plasma was observed up to $93 \%$, in erythrocytes - up to $34 \%$ and in brain tissue - up to $58 \%$, indicating a moderate toxicity [23]. Based on the principles of bioethics on the protection of vertebrates, the isolated effect of "Ivin" was not studied, because the selected doses of "Ivin" $13 \mathrm{mg} / \mathrm{kg}$ and $0.013 \mathrm{mg} / \mathrm{kg}$ are non-toxic to 
rats, but can reduce lipid peroxidation and have a membrane-stabilizing effect [20].

Experimental animals were examined daily. Changes in behaviour, signs of intoxication, death of animals were considered. Body weight was recorded once a week and dose adjustment of tested substances was performed according to body weight. For biochemical studies, blood was drawn from the femoral vein of rats with prior anaesthesia with carbon dioxide. Blood was collected into centrifuge tubes. To obtain serum, the blood was centrifuged in Elmi CM$6 \mathrm{M}$ centrifuge for 10 minutes at $1500 \mathrm{rpm}$.

To determine the nature of the combined action of Chlorpyrifos and "Ivin" in the dynamics (in 4, 9 and 13 weeks of exposure) the activity of cytolysis enzymes alanine aminotransferase (ALT) and aspartate aminotransferase (AST), as well as alkaline phosphatase (ALP), the content of crude protein, urea, total cholesterol, triglycerides and glucose in the serum was assessed. The study was performed at a biochemistry analyzer Vitalab Flexor E with a kit of reagents by BioSystems, Spain.

Since butyrylcholinesterase (EC 3.1.1.8, BCHE) and acetylcholinesterase (EC 3.1.1.7, ACHE) are informative biomarkers of Organophosphorus compounds effects [24, 25 ], the specific action of Chlorpyrifos and its combinations with "Ivin" was determined by the activity of BCHE in blood serum, by the activity of ACHE in erythrocytes and brain tissues with the use of methodology by Hesrtin S. [26] using a kit of reagents produced by LLC NPP Filisit-Diagnostics, Ukraine.

Statistical processing of research results was performed by standard methods of variation statistics using Student's t-test [27]. Arithmetic mean $(\mathrm{M})$, non-sampling error $(\mathrm{m})$, Student's t-test criterion and probable differences in obtained results $(\mathrm{P})$ were calculated.

Results and Discussion. Under the subchronic oral isolated action of Chlorpyrifos and combined action of Chlorpyrifos and "Ivin" on male Wistar Han rats in the studied doses no clinical symptoms of intoxication, death of animals were observed at all observation times. The behaviour of the animals in experimental groups did not differ from those in control group. Food and water consumption were identical to the control group.

The dynamics of animal body weight is shown in the Figure, which shows that under the isolated influence of Chlorpyrifos in weeks 4-8 there was a significant decrease in body weight of rats with the greatest effect at week $4(10.41 \%)$. The weight gain of the animals after weeks 4 and 8 reduced by $21.1 \%$ and $9.6 \%$ respectively ( $\mathrm{P} \leq 0.05)$. Body weight and its gain measurements under the combined action of Chlorpyrifos and "Ivin" on rats at different doses did not differ from the control group.

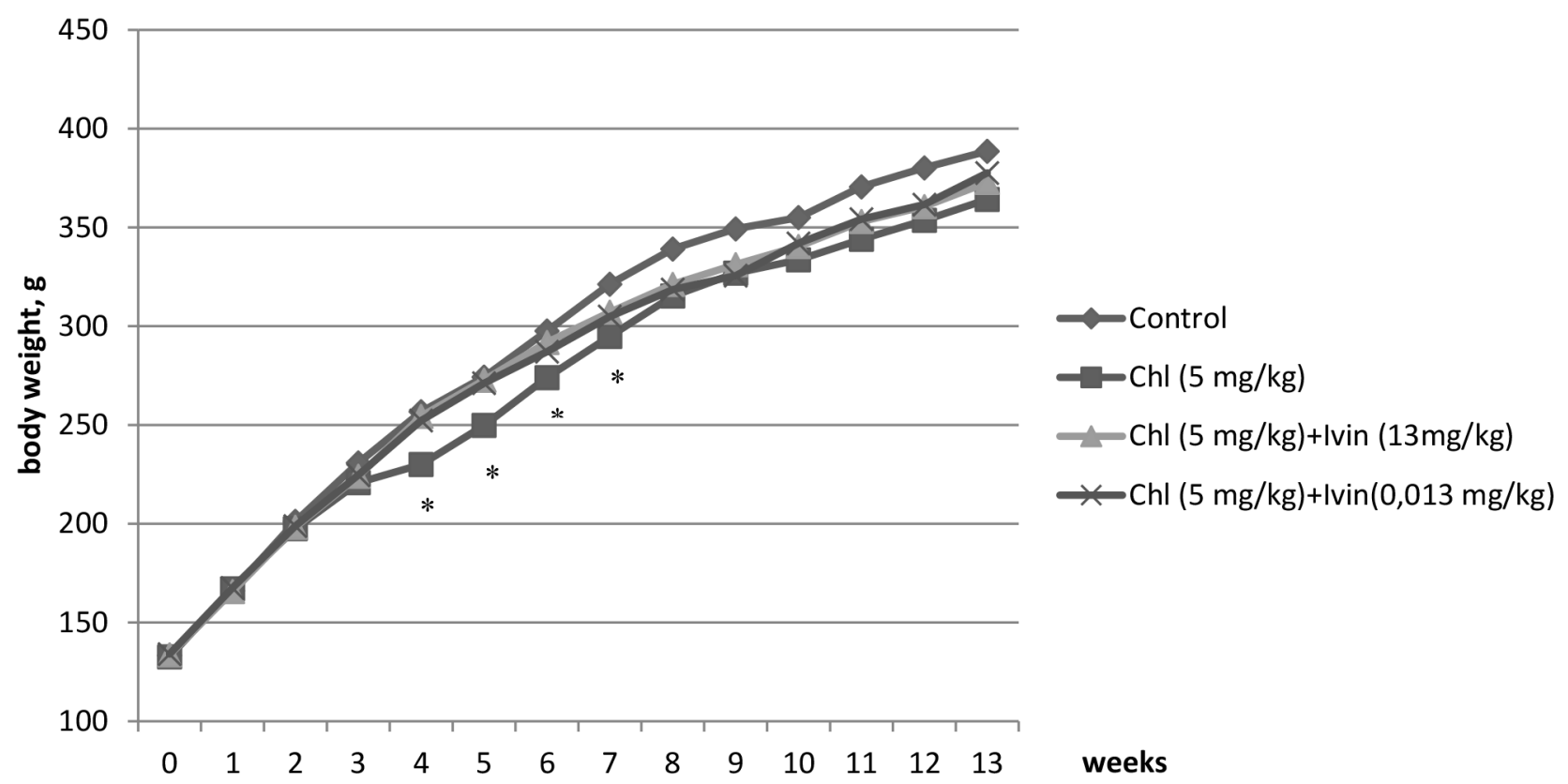

Fig. Dynamics of body weight of male rats under combined subchronic oral admission of Chlorpyrifos and "Ivin" ( $\mathrm{n}=15$ for $0-4$ weeks, $\mathrm{n}=10$ for $5-8$ weeks, $\mathrm{n}=5$ for $9-13$ weeks).

Notes: $\mathrm{n}-$ number of animals in the group; ${ }^{*}-\mathrm{P} \leq 0.05$. 
The results of studies of biochemical parameters of blood serum under the isolated action of Chlorpyrifos and under the combined action of Chlorpyrifos and "Ivin" in a subchronic experiment are given in Table 1.

As can be seen in Table 1, under the isolated action of Chlorpyrifos at a dose of $5 \mathrm{mg} / \mathrm{kg}$ of body weight per day after 4 weeks of studies, a significant increase in of urea and glucose levels in blood serum by $9.9 \%$ and $16.6 \%$ respectively was observed. At week 9 of studies, a significant increase in the activity of cytolysis enzymes (ALT and AST) by 26.7\%, 12.5\%; of urea and glucose levels by $17.3 \%$ and $17.6 \%$ in blood serum respectively was observed. After 13 weeks, there were similar changes in these indicators: a significant increase in the activity of ALT, AST; urea and glucose levels in blood serum by $32.6 \%, 12.0 \%, 14.3 \%$ and $13.7 \%$ respectively. During the whole research period the decrease tendency in the content of cholesterol with the greatest effect at the end of research by $15.8 \%$ was observed.

Reduced ChE inhibition activity (Table 2) occurred during the whole period of the research in all biological substrates. ChE inhibition in serum after weeks 4, 9 and 13 was $34.10 \%$; $29.61 \%$ and $41.29 \%$, in erythrocytes -39.28 $\% ; 42.12 \%$ and $45.54 \%$, in the brain $48.86 \%, 43.49 \%$ and $43.64 \%$ respectively.

As can be seen from the given above data, Chlorpyrifos at a dose of $5 \mathrm{mg} / \mathrm{kg}$ causes ChE inhibition in all studied bio substrates with the greatest effect in erythrocytes and brain. Regarding the severity of anticholinergic effect caused by Chlorpyrifos at a dose of $5 \mathrm{mg} / \mathrm{kg}$, the obtained data correspond to the referred data [23] and show that for its specific action Chlorpyrifos causes weak functional cumulation. Not expressed, but stable changes occurred in the activity of the enzymes of transamination of amino acids ALT and AST, in the content of urea and glucose, indicating a weak hepatotoxic effects and carbohydrate metabolism.

Under the combined action of Chlorpyrifos at a dose of $5 \mathrm{mg} / \mathrm{kg}$ and "Ivin" at a dose of $13 \mathrm{mg} / \mathrm{kg}$ probable changes in the activity of ALT and AST aminotransferases and content of glucose in blood serum in comparison to the control group were not observed, an increase in urea in blood serum after 9 and 13 weeks was $16.7 \%$ and $18.52 \%$ respectively. In comparison to the isolated action of Chlorpyrifos after
4 weeks there was a significant decrease in the content of urea in blood serum by $9.6 \%$, as well as after 13 weeks - an increase in cholesterol by $34.5 \%$. The data obtained indicate that "Ivin" contributes to the normalization of changes in these indicators caused by Chlorpyrifos.

The decrease in ChE activity in blood serum and erythrocytes was almost at the level with isolated exposure to Chlorpyrifos, but slightly less in brain. ChE inhibition in blood serum under the combined action of tested substances in 4, 9 and 13 weeks was $24.87 \%$, $24.54 \%$ and $43.76 \%$; in erythrocytes $27.60 \%, 40.32 \%$ and $40.04 \%$; in the brain $26.71 \%, 29.19 \%$ and $36.13 \%$ respectively.

In comparison to the isolated action of Chlorpyrifos, under the combined action of Chlorpyrifos and "Ivin" the inhibition of the ChE enzyme after 4, 9 and 13 weeks was in the serum: less by $9.23 \%$; $5.07 \%$ and more by $2.47 \%$ respectively; in erythrocytes - less by $11.68 \% ; 2.0 \%$ and $5.50 \%$ respectively; in the brain - less by $22.15 \%(\mathrm{P}<0.05), 14.30 \%$ and $7.51 \%$. As seen from the above data, under the combined admission to the body of rats of Chlorpyrifos and "Ivin" significant differences in the activity of the ChE, compared to the isolated impact of Chlorpyrifos, were observed in the brain after 4 weeks of research. This may indicate that under the combined influence of Chlorpyrifos and "Ivin" Chlorpyrifos probably breaks through the blood-brain barrier to the target of the biological action of acetylcholinesterase more slowly during this period.

Under the combined action of Chlorpyrifos at a dose of $5 \mathrm{mg} / \mathrm{kg}$ and "Ivin" at a dose of $0.013 \mathrm{mg} / \mathrm{kg}$ no significant alteration of the activity of ALT, AST and glucose content in the blood serum, compared to the control group was also observed. The increase in the level of urea in the blood serum was registered at all stages of the research at the level with the isolated action of Chlorpyrifos. In comparison to the isolated action of Chlorpyrifos after 13 weeks there was a significant increase in alkaline phosphatase activity by $14.5 \%$ and serum cholesterol by $28.07 \%$, but the changes in these indicators did not differ significantly from the control ones.

The decrease in ChE activity was observed in all bio substrates and was almost at the same level with the isolated action of Chlorpyrifos, 
Table 1

Biochemical parameters of blood serum of male rats under the combined subchronic oral exposure to

Chlorpyrifos and "Ivin" $(\mathrm{n}=5)$

\begin{tabular}{|c|c|c|c|c|c|}
\hline \multirow[b]{2}{*}{ Parameters } & \multirow[b]{2}{*}{$\begin{array}{l}\text { Research terms } \\
\text { (weeks) }\end{array}$} & \multicolumn{4}{|c|}{ Dose, $\mathrm{mg} / \mathrm{kg}$} \\
\hline & & Control & $\begin{array}{c}\text { Chlorpyrifos } \\
\text { (5 mg/kg) }\end{array}$ & $\begin{array}{c}\text { Chlorpyrifos } \\
\text { (5mg/kg) + } \\
\text { "Ivin" } \\
\text { (0.013 mg/kg) }\end{array}$ & $\begin{array}{c}\text { Chlorpyrifos } \\
\text { (5 mg/kg) + } \\
\text { "Ivin" } \\
\text { (13 mg/kg) }\end{array}$ \\
\hline \multirow{3}{*}{$\begin{array}{c}\text { ALP, } \\
\mu \mathrm{mol} / \mathrm{s} . \mathrm{L}\end{array}$} & 4 & $3.80 \pm 0.07$ & $3.51 \pm 0.17$ & $4.07 \pm 0.27$ & $4.00 \pm 0.28$ \\
\hline & 9 & $3.87 \pm 0.08$ & $3.67 \pm 0.19$ & $3.71 \pm 0.11$ & $3.73 \pm 0.10$ \\
\hline & 13 & $3.63 \pm 0.11$ & $3.24 \pm 0.14$ & $3.71 \pm 0.09$ & $3.59 \pm 0.13$ \\
\hline \multirow{3}{*}{$\begin{array}{c}\text { ALT, } \\
\mathrm{mmol} / 1 . \mathrm{h}\end{array}$} & 4 & $0.43 \pm 0.02$ & $0.53 \pm 0.04$ & $0.47 \pm 0.01$ & $0.48 \pm 0.03$ \\
\hline & 9 & $0.45 \pm 0.02$ & $0.57 \pm 0.03 *$ & $0.47 \pm 0.04$ & $0.48 \pm 0.01$ \\
\hline & 13 & $0.46 \pm 0.01$ & $0.61 \pm 0,04^{*}$ & $0.49 \pm 0.03$ & $0.50 \pm 0.02$ \\
\hline \multirow{3}{*}{$\begin{array}{c}\mathrm{AST}, \\
\mathrm{mmol} / \mathrm{l} . \mathrm{h}\end{array}$} & 4 & $0.72 \pm 0.03$ & $0.81 \pm 0.04$ & $0.77 \pm 0.04$ & $0.76 \pm 0.03$ \\
\hline & 9 & $0.81 \pm 0.03$ & $0.91 \pm 0.03 *$ & $0.86 \pm 0.04$ & $0.87 \pm 0.03$ \\
\hline & 13 & $0.91 \pm 0.02$ & $1.01 \pm 0.03 *$ & $0.95 \pm 0.04$ & $0.99 \pm 0.04$ \\
\hline \multirow{3}{*}{$\begin{array}{c}\text { Crude protein, } \\
\mathrm{g} / 1\end{array}$} & 4 & $68.85 \pm 0.80$ & $68.89 \pm 1.10$ & $64.73 \pm 2.47$ & $65.02 \pm 1.81$ \\
\hline & 9 & $65.48 \pm 0.76$ & $68.67 \pm 2.36$ & $68.17 \pm 1.51$ & $67.09 \pm 1.29$ \\
\hline & 13 & $63.84 \pm 0.93$ & $67.47 \pm 2.80$ & $65.22 \pm 2.29$ & $60.12 \pm 3.82$ \\
\hline \multirow{3}{*}{$\begin{array}{l}\text { Urea, } \\
\mathrm{mmol} / \mathrm{l}\end{array}$} & 4 & $7.31 \pm 0.24$ & $8.03 \pm 0.16 *$ & $7.97 \pm 0.13 *$ & $7.26 \pm 0.16 \bullet$ \\
\hline & 9 & $7.06 \pm 0.19$ & $8.28 \pm 0.19 *$ & $8.44 \pm 0.23 *$ & $8.24 \pm 0.19 *$ \\
\hline & 13 & $8.26 \pm 0.18$ & $9.44 \pm 0.23 *$ & $9.67 \pm 0.18 *$ & $9.79 \pm 0.23 *$ \\
\hline \multirow{3}{*}{$\begin{array}{c}\text { Cholesterol, } \\
\text { mmol/1 }\end{array}$} & 4 & $2.09 \pm 0.06$ & $1.99 \pm 0.23$ & $2.22 \pm 0.06$ & $2.23 \pm 0.14$ \\
\hline & 9 & $1.84 \pm 0.06$ & $1.75 \pm 0.10$ & $2.02 \pm 0.15$ & $1.91 \pm 0.14$ \\
\hline & 13 & $2.03 \pm 0.12$ & $1.71 \pm 0.15$ & $2.19 \pm 0.13$ & $2.30 \pm 0.20 \bullet$ \\
\hline \multirow{3}{*}{$\begin{array}{l}\text { Triglycerides, } \\
\text { mmol/1 }\end{array}$} & 4 & $0.66 \pm 0.04$ & $0.63 \pm 0.05$ & $0.68 \pm 0.08$ & $0.71 \pm 0.07$ \\
\hline & 9 & $0.63 \pm 0.03$ & $0.54 \pm 0.05$ & $0.62 \pm 0.07$ & $0.54 \pm 0.09$ \\
\hline & 13 & $0.71 \pm 0.05$ & $0.59 \pm 0.04$ & $0.71 \pm 0.08$ & $0.67 \pm 0.06$ \\
\hline \multirow{3}{*}{$\begin{array}{c}\text { Glucose, } \\
\text { mmol } 1\end{array}$} & 4 & $3.55 \pm 0.17$ & $4.14 \pm 0.19 *$ & $3.72 \pm 0.21$ & $3.92 \pm 0.18$ \\
\hline & 9 & $3.87 \pm 0.19$ & $4.55 \pm 0.16 *$ & $4.06 \pm 0.24$ & $4.40 \pm 0.22$ \\
\hline & 13 & $3.83 \pm 0.12$ & $4.40 \pm 0.14 *$ & $4.18 \pm 0,17$ & $4.22 \pm 0,14$ \\
\hline
\end{tabular}

Notes: $\mathrm{n}-$ number of animals in the group; ${ }^{*}-\mathrm{P}<0.05$ in relation to the control;

- $-\mathrm{P}<0.05$ in relation to Chlorpyrifos. 
Activity of cholinesterase in some biological substrates of male rats under combined subchronic oral admission of Chlorpyrifos and "Ivin" $(n=5)$

\begin{tabular}{|c|c|c|c|c|c|}
\hline \multirow[b]{2}{*}{ Parameters } & \multirow[b]{2}{*}{$\begin{array}{l}\text { Research } \\
\text { terms } \\
\text { (weeks) }\end{array}$} & \multicolumn{4}{|c|}{ Dose, $\mathrm{mg} / \mathrm{kg}$} \\
\hline & & Control & $\begin{array}{c}\text { Chlorpyrifos } \\
\text { (5 mg/kg) }\end{array}$ & $\begin{array}{c}\text { Chlorpyrifos } \\
\text { (5mg/kg) + } \\
\text { "Ivin" } \\
(0.013 \mathrm{mg} / \mathrm{kg})\end{array}$ & $\begin{array}{c}\text { Chlorpyrifos } \\
\text { (5 mg/kg) + } \\
\text { "Ivin" } \\
(13 \mathrm{mg} / \mathrm{kg})\end{array}$ \\
\hline \multirow{3}{*}{$\begin{array}{l}\text { Butyrylcholinesterase } \\
\text { in blood serum } \\
(\mathrm{BCHE}), \mu \mathrm{mol} /(\mathrm{h} \cdot \mathrm{L})\end{array}$} & 4 & $72.82 \pm 1.59$ & $47.99 \pm 3.23 *$ & $50.18 \pm 2.35 *$ & $54.71 \pm 3.99 *$ \\
\hline & 9 & $69.97 \pm 2.06$ & $49.25 \pm 2.06 *$ & $48.53 \pm 3.23 *$ & $52.80 \pm 2.94 *$ \\
\hline & 13 & $73.36 \pm 2.76$ & $43.07 \pm 4.00 *$ & $43.17 \pm 3.65 *$ & $41.26 \pm 4.39 *$ \\
\hline \multirow{3}{*}{$\begin{array}{l}\text { Acetylcholinesterase } \\
\text { in erythrocytes } \\
(\mathrm{ACHE}), \mu \mathrm{mol} /(\mathrm{h} \cdot \mathrm{L})\end{array}$} & 4 & $77.86 \pm 2.65$ & $47.28 \pm 4.88 *$ & $48.81 \pm 4.11 *$ & $56.37 \pm 4.88 *$ \\
\hline & 9 & $78.30 \pm 2.65$ & $45.32 \pm 2.76^{*}$ & $43.23 \pm 2.82 *$ & $46.88 \pm 3.99 *$ \\
\hline & 13 & $77.86 \pm 2.65$ & $42.40 \pm 3.29 *$ & $43.93 \pm 1.65 *$ & $45.91 \pm 3.12 *$ \\
\hline \multirow{3}{*}{$\begin{array}{l}\text { Acetylcholinesterase } \\
\text { in brain tissues } \\
(\mathrm{ACHE}), \mu \mathrm{mol} /(\mathrm{h} \cdot \mathrm{L})\end{array}$} & 4 & $347.71 \pm 12.35$ & $177.83 \pm 14.11^{*}$ & $215.09 \pm 15.58^{*}$ & $254.82 \pm 20.58 *$ \\
\hline & 9 & $338.94 \pm 12.35$ & $191.53 \pm 16.17^{*}$ & $209.34 \pm 19.99^{*}$ & $240.02 \pm 16.17 *$ \\
\hline & 13 & $342.77 \pm 9.41$ & $193.17 \pm 16.17^{*}$ & $201.94 \pm 16.46^{*}$ & $218.93 \pm 23.52 *$ \\
\hline
\end{tabular}

Notes: $\mathrm{n}-$ number of animals in the group; ${ }^{*}-\mathrm{P}<0.05$ in relation to the control group;

$-\mathrm{P}<0.05$ in relation to Chlorpyrifos.

except for the brain, where the ChE activity was $10.72 \%$ higher under the combined action compared to the isolated action of Chlorpyrifos.

Thus, the obtained data indicate that "Ivin" in doses of $13 \mathrm{mg} / \mathrm{kg}$ and $0.013 \mathrm{mg} / \mathrm{kg}$ alleviates the course of Chlorpyrifos intoxication, as evidenced by the normalization of body weight, cytolysis enzyme activity, glucose levels, serum cholesterol, and reduced ACHE inhibition activity in the brain.

Data on the reduction of ACHE inhibition in brain tissues under subchronic exposure to Chlorpyrifos combined with "Ivin" correlate with previously obtained results on the reduction of the toxic effect of Chlorpyrifos under acute sequential action of "Ivin" at a dose of

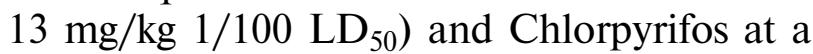
dose of $75 \mathrm{mg} / \mathrm{kg}\left(\mathrm{LD}_{50}\right)$ [20]. Thus, as shown in the paper [20], under the sequential single oral impact of Chlorpyrifos and "Ivin" in specified doses the rate of deaths of animals was lower; cholinergic intoxication symptoms typical for Chlorpyrifos were not observed.
ChE inhibition activity in serum, red blood cells and the brain was less pronounced and ChE activity recovery was faster than under the isolated action of Chlorpyrifos.

As can be seen from previously obtained data [20] under the subchronic isolated oral action of "Ivin" on rats (at doses of $13 \mathrm{mg} / \mathrm{kg}$ and $0.013 \mathrm{mg} / \mathrm{kg}$ ) most pronounced reduction in malondialdehyde (final product of lipid peroxidation) in the membranes of mitochondria of hepatocytes was observed after 1 month of research, this coincides with a decrease in the toxic effect during this period under the combined action of "Ivin" with Chlorpyrifos. Discovered fact demonstrates that the reduction of the toxic effects of Chlorpyrifos under the combined action with "Ivin" may be due to the antioxidant and membrane-stabilizing properties of the latter, which requires further research.

Conclusions. 1. Chlorpyrifos in isolated oral administration for 13 weeks has a weak hepatotoxic effect, as evidenced by an increase in cytolysis enzymes, glucose and urea levels in 


\section{ORIGINAL RESEARCH \\ TOXICOLOGY OF PESTICIDES}

serum and causes a moderate anticholinesterase effect.

2. Ivin under combined admission with Chlorpyrifos eliminates the hepatotoxic effects of Chlorpyrifos and reduces its anticholinergic effects in the brain, which contributes to a less severe intoxication.
Acknowledgements.

The author expresses her sincere gratitude to senior laboratory assistant Didur N.V., senior laboratory assistant with higher education Klyuchynska T.I., leading engineer Nadtochiy O.P. for assistance in conducting this experimental study.

\section{REFERENCES}

1. Moser VC, Casey M, Hamm A, Carter WHJr, Simmons JE, Gennings C. Neurotoxicological and Statistical Analyses of a Mixture of Five Organophosphorus Pesticides Using a Ray Design. Toxicological Sciences. 2005; 86(1): 101-15, https://doi.org/10.1093/toxsci/kfi163

2. Mansour SA, Heikal TM, Mossa AH, Refaie AA. Toxic effects of five insecticides and their mixture on male albino rats. J. Egypt. Soc. Toxicol. 2008; 39: 85-94.

3. Baygonova KS, Saparbekov MK. Osobennosti izmeneniya biokhimicheskikh pokazateley krovi i otsenka riska pri kombinirovannom deystvii pestitsidov (Sumi-alfa, Lontrim, tabachnaya pyl) $\mathrm{v}$ eksperimente. [Features of changes in blood biochemical parameters and risk assessment under the combined action of pesticides (Sumi-alpha, Lontrim, tobacco dust) in the experiment]. Health and Disease. 2008; 4(70): 29-30.

4. Vera Lu cia Scherholz de Castroa, Selma Helo1 sa Chiorato. Effects of separate and combined exposure to the pesticidesmethamidophos and chlorothalonil on the development of suckling rats. Int. J. Hyg. Environ.-Health. 2007; 210

169 176.https://doi.org/10.1016/j.ijheh.2006.09.003

5. Palkhade R, Yadav S, Mishra S, Muhamed J. Acuteoral toxicity of pesticide combination (acephate $50 \%$ and imidacloprid $1.8 \%$ as active ingredients) in Sprague-Dawley rats, Veterinary World. 11(9): 1291-97. doi:10.14202/vetworld. 2018; 1291-97.

6. Rakitskiy VN, Sinitskaya TA, Batishchev IS. Kombinirovannoe deystvie pestitsida $\mathrm{i}$ antidota proizvodstvennogo naznacheniya [Combined effect of a pesticide and antidote of industrial use]. Toxicological review. 2011; 2(107): 2-5.

7. Abhishek A, Ansari NG, Shankhwar SN, Jain A, Singh V. (2014). In vitro toxicity evaluation of low doses of pesticides in individual and mixed condition on human keratinocyte cell line, Bioinformation, 2014; 10(12): 716-20. DOI: 10.6026/97320630010716.

8. Pelo I, Omelchuk S, Bardov V, Sasinovich L. Funkcionaljnyj stan i struktura pechinky shhuriv za umov subkhronichnoji diji sumishej pestycydiv, shho zastosovujutjsja v ovochivnyctvi [Functional state of liver in white rats under conditions of short term intoxication caused by pesticides mixtures used in vegetable growing]. Environment\&Health. 2010; 1: 22-6.

9. Pelo IM. Problema rezystentnosti shkodochynnykh aghentiv do diji pestycydiv, jaki zastosovujutjsja $\mathrm{v}$ ovochivnyctvi ta sposoby jiji usunennja (analitychnyj oghljad literatury) [The problem of deleterious agents' resistance to the effect of pesticides used in vegetable growing and ways of its elimination (analytical review of literature)]. Hygiene of Populated Places. 2015; 66: 95-103.

10. Rizzatia V, Briand O, Guilloua H, Gamet-Payrastrea L. Effects of pesticide mixtures in human and animal models: An update of the recent literature. Chemico-biological interactions. 2016; 254: DOI: 10.1016/j.cbi.2016.06.003.

11. Kocaman AY, Topaktas M. Genotoxic effects of a particular mixture of acetomiprid and alpha-cypermetrin on chromosome aberration? Sister chromatid exchange? And micronucle us formation in human peripheral blood lymphocytes, Environmental Toxicology. 2010; 25(2): 157-68. DOI: https://doi.org/10.1002/tox.20485

12. Ilyushina NA, Revazova YA. Genotoksicheskaya aktivnost smesey pestitsidov [Genotoxic activity of the pesticide mixtures]. Toxicological Review. 2020; (3): 9-13. https://doi.org/10.36946/0869-7922-2020-3-9-13.

13. Zhu W, Schmehl DR, Mullin CA, Frazier JL. Four common pesticides, their mixtures and a formulation solvent in the hive environment have high oral toxicity to honey bee larvae. PLoS ONE. 2014; 9(1): e77547. https://doi:10.1371/ journal.pone. 0077547

14. Chen J, Saleem M, Wang C, Liang W, Zhang Q. Individual and combined effects of herbicide tribenuron-methyl and fungicide tebuconazole on soil earthworm Eiseniafetida. Sci Rep. 2018; 8: 2967. https://doi.org/10.1038/s41598018-21288-y

15. YanhuaWang, ChaoXu, DouWang, HongbiaoWeng, GuilingYang, DongmeiGuo, RuixianYu, XinquanWang, QiangWang. Combined toxic effects of fludioxonil and triadimefon on embryonic development of zebrafish (Danio rerio). Environmental Pollution. 2020; 260: 114105. https://doi.org/10.1016/j.envpol.2020.114105

16. New plant growth regulators: basic research and technologyes of application. Monograph. Editors. Ponomarenko SP, Iutynska HO. Kyiv, Nichlava. 2011. 210 c.

17. Titov VN, Smyslov DG, Dmitrieva GA, Bolotova OI. Regulyatory rosta rasteniy kak biologicheskiy faktor snizheniya urovnya tyazhelykh metallov $\mathrm{v}$ rastenii [Plant growth regulators as a biological factor in reducing the level of heavy metals in a plant]. Bulletin of Agrarian Science. 2011; 31(4): 4-6.

18. Korotchenko IS, Kiriyenko NN. Vliyanie regulyatora rosta rasteniy «Ribav-Ekstra» na stepen toksichnosti tyazhelykh metallov dlya test-rasteniy [Growth regulator «Ribavextra» influence on heavy metals toxicity degree for testplants]. The Bulletin of KrasGAU. 2013; 9: 117-22.

19. Ryabchenko NA, Mochalov VV, Lisitskaya SM. Vliyanie regulyatorov rosta rasteniy na vozmozhnost snizheniya insektitsidnoy nagruzki $v$ agrotsenozakh ozimoy pshenitsy. [Effect of plant growth regulators on possibility of reduction of insecticide load in agrocenoses of winter wheat]. Visnyk of Dnipropetrovsk University. Biology, Ecology. 2006; 14(1): 160-4.

20. Vasetska OP, Zhminko PG. "Paradoksalnye" effekty v toksikologii, mekhanizmy i metodicheskie podkhody $\mathrm{k}$ ikh prognozirovaniyu (po dannym literatury i sobstvennykh issledovaniy) ["Paradoxical" effects in toxicology, mechanisms and methodological approaches to prediction (according to the literature and our own research)]. 


\section{ORIGINAL RESEARCH \\ TOXICOLOGY OF PESTICIDES}

Suchasni problemy toksykolohiyi, kharchovoyi ta khimichnoyibezpeky. 2015; 1-2: 54-66.

21. Vasetska OP. Kombinirovannoe deystvie regulyatorov rosta rasteniy na osnove proizvodnykh N-oksid piridina i nekotorykh pestitsidov razlichnykh khimicheskikh grupp [Combined action of plant growth regulators based on pyridine n-oxide derivatives and some pesticides of different chemical groups]. Suchasni problemy toksykolohiyi, kharchovoyi ta khimichnoyi bezpeky. 2017; 3: 26-33.

22. Perelik pestycydiv $\mathrm{i}$ aghrokhimikativ, dozvolenykh do vykorystannja v Ukrajini [List of pesticides and agrochemicals approved for use in Ukraine (Official document)]. Kyiv: Univest Media. 2018; 1040 p.

23. IPCS INCHEM Home. Pesticide residues in food. CHLORPYRIFOS. Toxicological evaluations., Rome, 20-29 September 1999. http://www.inchem.org/documents/jmpr/ jmpmono/v99pr03.htm

24. Makhaeva GF, Rudakova EV, Sigolaeva LV. Investigation of Esterase Status as a Complex Biomarker of Exposure to Organophosphorus Compounds. Toxicological Problems [editor: Christophor Dishovsky and Julia RadenkovaSaeva]. Bulgarian Toxicological Society. Military Publishing House, Sofia, Bulgaria. 2014; 15-26.

25. Fedchenko O, Zhminko P. Biomarkery ekspozyciji ta efektu fosfororghanichnykh spoluk (oghljad danykh literatury ta rezuljtaty vlasnykh doslidzhenj) [Biomarkers of exposure and effect of organophosphorus compounds (literature review and results of own studies)]. Ukrainian Journal of Modern Problems of Toxicology. 2018; 4: 19-35.

26. Hestrin S. The reaction of acetilcholine and other carboxylic acid derivatives with hydroxyiamine and its analytical application. J.Biol. Chem. 1949; 180: 249-62.

27. Lapach SN, Gubenko AV, Babich PN. Statistika v nauke i biznese [Statistics in science and business]. Kiev: Morion. 2002.

\section{ТОКСИКОДИНАМІКА ЗА СУМІСНӦ̈ ДІЇ ХЛОРПІРИФОСУ ТА ІВІНУ ПРИ ТРИВАЛОМУ НАДХОДЖЕННІ ДО ОРГАНІЗМУ}

О.П. Васецька

ДП «Науковий центр превентивної токсикології, харчової та хімічної безпеки імені академіка Л.І. Медведя Міністерства охорони здоров'я України», м. Київ, Україна

PЕЗЮМЕ. Комбінована дія пестицидів є однією з проблем токсикології, оскільки в порівнянні з окремими діючими речовинами їх суміші можуть сприяти підвищенню токсичності та відділених ефектів дії, що є ризиком для здоров'я людини. Відомо, що регулятори росту рослин (РРP) при сумісному застосуванні з пестицидами сприяють зниженню норми витрат пестицидів, накопиченню їх і важких металів у рослинах, зменшують гостру токсичність ксенобіотиків. Комбінована дія PPP і пестицидів при тривалому надходженні до організму не досліджена, що є актуальним завданням профілактичної токсикології.

Мета досліджень. З’ясувати характер токсичного впливу Хлорпірифосу та Івіну за їх сумісної дії при субхронічному пероральному надходженні до організму.

Матеріали і методи. Сумісна дія інсектициду Хлорпірифосу і РPP Івіну (2,6-диметил-N-оксид піридину) вивчена на щурах-самиях Wistar Han. Речовини вводили перорально, зондом упродовж 13 тижнів, Хлорпірифос - у вигляді водної емульсії з ОП-10 у дозі 5 мг/кг (1/15 ЛД 50 ), Івін - у вигляді водного розчину в дозах 13 мг/кг і 0,013 мг/кг (відповідно $1 / 100$ і 1/100000 ЛД 50 ), контрольній групі щурів вводили воду з ОП-10. Реєстрували ознаки інтоксикації, через 4, 9 i 13 тижнів визначали масу тіла, біохімічні показники сироватки крові (активність ферментів АЛТ, АСТ, лужної фосфатази, вміст загального білка, сечовини, холестерину, тригліцеридів, глюкози з використанням наборів реактивів фірми «ВіоSуstетs» (Іспанія), активність холінестерази (ХЕ) у сироватці крові, еритроцитах і тканинах головного мозку визначали за методом Hеsrtin $S_{3}$ використанням набору реактивів фірми «Фелісіті», (Україна).

Результати. У піддослідних груп щурів клінічних ознак інтоксикації не виявлено. За ізольованої дії Хлорпірифосу спостерігалось вірогідне зниження маси тіла, інгібування активності ХЕ в усіх біосубстратах, з найбільшим ефектом у головному мозку (на 48,8\%), збільшення (через 9 і 13 тижнів) активності АЛТ і АСТ на 26,7-32,6\%, 12,5-12,0\%, незначне, але вірогідне підвищення рівня сечовини і глюкози у сироватці крові до 17,3\% і 17,6\% відповідно. При сумісній дї Хлорпірифосу та Івіну в указаних дозах маса тіла шурів була на рівні контролю, зниження активності ХЕ спостерігалось у всіх біосубстратах і було практично на рівні ізольованого впливу Хлорпірифосу. Мала місие тенденція до зменшення інгібування активності ХЕ у тканинах головного мозку, а за сумісного впливу Хлорпірифосу з Івіном у вищій дозі через 4 тижні цей ефект був вірогідним $(22,15 \%, p<0,05)$.

Висновки. Хлорпірифос при ізольованій пероральній дії упродовж 13 тижнів чинить слабку гепатотоксичну дію, про що свідчить підвищення ферментів цитолізу, рівня глюкози, сечовини в сироватиі крові, $i$ викликає помірний антихолінестеразний ефект. Івін при сумісному надходженні до організму з Хлорпірифосом нівелює гепатотоксичну дію Хлорпірифосу $i$ зменшує його антихолінестеразний ефект у головному мозку, що сприяє більш легкому перебігу інтоксикації.

Ключові слова: Хлорпірифос, Івін, гепатотоксична дія, антихолінестеразний ефект.

\section{ТОКСИКОДИНАМИКА ПРИ СОВМЕСТНОМ ДЕЙСТВИИ ХЛОРПИРИФОСА И ИВИНА ПРИ ДЛИТЕЛЬНОМ ПОСТУПЛЕНИИ В ОРГАНИЗМ}

О.П. Васецкая

ГП «Научный центр превентивной токсикологии, пищевой и химической безопасности имени академика Л. И. Медведя Министерства здравоохранения Украины», г. Киев, Украина

PЕЗЮМЕ. Комбинированное действие пестицидов является одной из проблем токсикологии, поскольку в сравнении с отдельными действующими веществами, их смеси могут способствовать повышению токсичности и отдаленных эффектов действия, что является риском для здоровья человека. Известно, что регуляторы роста растений (РРP) при совместном применении с пестицидами способствуют снижению нормы расхода пестицидов, накоплению их и тяжелых металлов 


\section{ORIGINAL RESEARCH \\ TOXICOLOGY OF PESTICIDES}

в растениях, уменьшают острую токсичность ксенобиотиков. Комбинированное действие РРР и пестицидов при длительном поступлении в организм не исследовано, что является актуальной задачей профилактической токсикологии.

Цель исследований. Выяснить характер токсического действия Хлорпирифоса и Ивина при их совместном субхроническом пероральном поступлении в организм.

Материалы и методы. Совместное действие инсектицида Хлорпирифоса и РРР Ивина (2,6-диметил- $N$-оксид пиридина) изучено на крысах-самцах Wistar Нап. Вещества вводили перорально, зондом в течение 13 недель, Хлорпирифос - в виде водной эмульсии с ОП-10 в дозе 5 мг/кг (1/15 ЛД О) , Ивин - в виде водного раствора в дозах 13 мг/кг и 0,013 мг/кг (соответственно 1/100 и 1/100000 ЛД 50 ), контрольной группе крыс вводили воду с ОП-10. Регистрировали признаки интоксикации, через 4, 9 и 13 недель определяли массу тела, биохимические показатели сыворотки крови (активность ферментов АЛТ, АСТ, щелочной фосфатазы, содержание общего белка, мочевины, холестерина, триглицеридов, глюкозы с использованием наборов реактивов фирмы «BioSysteтs» (Испания), активность холинэстеразы (ХЕ) в сыворотке крови, эритроцитах и тканях головного мозга определяли методом Неsrtin $S$ с использованием набора реактивов фирмы «Фелисити» (Украина).

Результаты. У подопытных групп крыс клинических признаков интоксикации не обнаружено. При изолированном действии Хлорпирифоса наблюдалось достоверное снижение массы тела, ингибирование активности ХЕ во всех биосубстратах, с наибольшим эффектов в головном мозге (на 48,8\%), увеличение (через 9 и 13 недель) активности АЛТ и АСТ на 26,7$32,6 \%, 12,5$ - 12,0\%, незначительное,но достоверное повышение уровня мочевины и глюкозы в сыворотке крови до 17,3\% и 17,6\% соответственно. При совместном действии Хлорпирифоса и Ивина в указанных дозах масса тела крыс была на уровне контроля, снижение активности ХЕ наблюдалось во всех биосубстратах и было практически на уровне изолированного влияния Хлорпирифоса. Наблюдалась тенденция к уменьшению ингибирования активности ХЕ в тканях головного мозга, а при совместном влиянии Хлорпирифоса с Ивином в большей дозе и через 4 недели этот эффект был достоверным $(22,15 \%, p<0,05)$.

Выводы. Хлорпирифос при изолированном пероральном действии в течение 13 недель оказывает слабое гепатотоксическое действие, о чем свидетельствует повышение ферментов цитолиза, уровня глюкозы, мочевины в сыворотке крови и вызывает умеренный антихолинэстеразный эффект. Ивин при совместном поступлении в организм с Хлорпирифосом нивелирует гепатотоксическое действие Хлорпирифоса и уменьшает его антихолинэстеразный эффект в головном мозге, что способствует более легкому течению интоксикации.

Ключевые слова: Хлорпирифос, Ивин, гепатотоксическое действие, антихолинэстеразный эффект.

Received 07.07.2020 